\title{
Plyndringen af Aabenraa 1523
}

\section{Af Johan Hvidtfeldt}

Følgende lille beretning om plyndringen af Aabenraa har især interesse, fordi den er den æeldste bevarede skildring af historiske begivenheder med Aabenraa som skueplads. Den er skrevet 1607 af Claus Esmarch, som allerede den 6. januar 1603 havde faaet bestalling som amtsskriver i Aabenraa, og som dette aar blev medlem af raadet og aaret efter, den 4. juni 1608, valgtes til borgmester af 24 borgere. Hans virksomhed som borgmester blev dog ikke af lang varighed. I 1610 - samme aar som størstedelen af byen blev lagt øde ved den store brand -blev han skudt ned udenfor byen. Det blev snart opklaret, at hans kone og svigerforældre stod bagved mordet. Hertug Johan Adolf gav ordre til, at der skulde afholdes pinligt forhør i sagen, og tre dage senere blev svigerfaderen Wulff Kalund, amtsforvalter i Løgumkloster, tidligere i Aabenraa, underkastet forhør i torturkammeret. Den 12. juni var det svigermoderen Margrete, f. von Eitzen, der blev taget under behandling af bødelen. Af hendes tilstaaelse fremgik bl. a. følgende: "... Hun bekender, at hun for udaaden har haft kendskab dertil og indvilget $i$, at Wulff havde tinget med og købt skytten til at lade Esmarch ombringe. Angaaende datteren bekender hun, at hendes datter ofte med graad og bønner havde begæret, at hun og Wulff vilde skaffe hende af med Esmarch .. . Hendes datter Anne havde vel vidst, at misdæderen var købt til at ombringe hendes mand «. Selve drabsmanden, Jørgen Skytt, undslap. Endnu syv aar senere var han paa fri fod, idet kongen da gav sine lensmænd ordre til at hjælpe Jørgen Esmarch med at finde ham. Men de virkelige ophavsmænd, Margrete og Wulff Kalund, led deres velfortjente straf paa galgebakken nordfor 
byen $\left.^{\mathrm{i}}\right)$. Herom fortælles følgende $i$ den saakalte Fladstendagbog: Anno 1610, 14. juni blev Wuluff Caalundt rettet paa Arnbierig, ihjelslagen med et hjul og ligger sammesteds derpaa, og hans hustru Margareta halshugget paa Kirkebjerget .... Og Hr. Jurgen Lundt af Heldewaide henrømmede fra begge sine kirker i samme tid for samme sag. Item Bertram Jensen i Bedistede stillede nogle dage tilforn borgen for samme forræderiske sag for 1000 rigsdaler til min naadige herre til Gottorp ${ }^{2}$ ).

Beretningen findes indført i Claus Esmarchs optegnelsesbog, som er paabegyndt 1607. Denne bog er af stor betydning for studiet af Aabenraa bys historie, idet den foruden en afskrift af den plattyske oversættelse af skraaen fra 1335 ogsaa indeholder den ældste afskrift af Aabenraa bys stadsret $\left.{ }^{3}\right)$. Desuden findes der i den forskellige optegnelser, hvoraf flere stammer fra tiden efter 1610 .

Fortællingen om begivenhederne i 1523 er skrevet paa platıysk. Selvom den maaske ikke i alle enkeltheder er historisk korrekt, gengiver den i hvert fald den tradition om de frygtelige overfald, som paa den tid levede $\mathbf{i}$ byen. Den lyder $\mathrm{i}$ dansk oversættelse saaledes:

Efter Guds byrd 1522 (d. v. s. 1523) blev kong Christiern fordrevet fra Danmark af sin onkel hertug Frederik og rigsraadet med hjælp af lybækkerne og andre omliggende stæder. Derefter søndag før palmesøndag (det er den 22. marts) kom de lybske ryttere til Aabenraa (Apenra) om natten, mens man sov, med bøsser og svært skyts, med vaaben og værge og indtog byen og borgen; nogle borgere dræbte de, nogle huse brændte de af, nogle greb og bandt de og pinte baade gejstlige og verdslige. Alle de som undslap, kvinder og mænd med deres nøgne børn; løb til skoven, ud paa marken og til vandet, før de kunde gemme og skjule sig. Da brød de deres kister, deres skabe op

1) Aabenraa byarkiv: Claus Esmarchs Optregnelsesbog. Aabenraa reıısbetjentarkiv: Sagior afleveret fra Kiel. C.XIX. 6. nir. 6.

") Sprogforeningens Almanak 1918, side 61 .

3) Denne sammen med skraaen trykt (efter dette haandskrift) i Thorsen: De medl Jydske Lov beslægtede stadsretter for Slesvig, Flensborg, Aabenraa og Haderslev 181-211, jvnfr. indlediningen 57-62. 
og tog der udaf penge, guld, sølv, klæder, klenodier og alt, hvad de fandt.

Tidlig om morgenen den næste dag brød de ind i kirken og slog kister, skabe og lader i stykker og tog derudaf en mængde penge og gods, senge, sengeklæder, lagener, dækkener, kander og krukker. Derefter løb de til skovs og ud paa marken, tog heste og køer og lod dem drive bort. Andre grovvarer, baljer, bryggerkedler, kander og krukker, korn, malt, flæsk, fisk, kød og al slags husgeraad solgte de til bønderne rundt om. Hvad de ikke kunde sælge, tog de bort med sig og odelagde byen og tilintetgjorde alt. Da blev bysbøgerne, registrene og alt, som de skulde rette sig efter, ilde tilredt, ødelagt og kom bort. Nogen tid derefter forsamlede byens folk sig igen og fandt trøst i deres byskraa og privilegier, som naadig er givet og forundt dem af herrer og fyrster. 